\title{
DISSEMINATION OF WASTE DANGERS TO ENVIRONMENTAL HEALTH IN ANGGADITA VILLAGE
}

\author{
Dudi Permana, Dian Primanita, Oktasari, Winda Widyanty, and Noermijati \\ Universitas Mercu Buana Jakarta, Indonesia \\ Unversitas Brawijaya, Indonesia.
}

\begin{abstract}
The danger of rubbish dump on health is an important thing for residents who live around the Citarum watershed, especially Anggadita Village. In this Community Service, it provides an understanding of the dangers of rubbish dump for health and how to maintain health in the surrounding environment. Barriers are still being experienced from the existence of the community to be caring and aware to maintain health and not to hoard or litter. How to overcome problems that occur in the partner community as described, the Community Partnership Program offers several methods of approach that can help in solving existing problems, Dissemination of the danger of waste dumps on environmental health, Dissemination of ways to protect environmental health, Dissemination of ways to protect environmental health and Assistance to the trainees.
\end{abstract}

Keywords: Waste, Health, and Environment

\section{Introduction}

Determination of waste management policies and strategies by the Government has been mandated in Law Number 18 Year 2008, in order to improve public health and good environmental quality. In addition, the Government is also responsible for ensuring the implementation of a universal waste management system.

Rural areas, generally have complex geographical conditions, limited infrastructure and village service facilities, infrastructure and accessibility / transportation. In addition, it is not uncommon for rural areas to have a considerable distance from the city center. So that it takes a strategy in managing waste in rural areas. The results of a survey conducted by Siliwangi Kodam III recorded 20,462 tons of organic and inorganic waste dumped into the Citarum River per day. Every day the Citarum River receives 1,500 tons of waste from various types ranging from household waste and industrial waste. These rubbish will eventually accumulate in the Saguling Reservoir so that it disrupts the operation of the turbines at the Saguling Hydroelectric Power Plant to supply electricity from Java - Bali. Even so, the problem of waste in Anggadita Village especially Sukajaya Hamlet must be resolved from many aspects. Starting from the addition of the fleet, routine transportation of waste, and no less important is the role of the community to participate in managing waste. So that the waste problem is not only burdened by the local Government Sanitation Office. Therefore, an active role of the community is needed in managing waste. For this reason, he hopes that the community can continue to develop waste banks, reduce, reuse, recycle (3R), composting and others in their respective regions.

\section{Literatur Review}

\section{Definition of Waste}

According to the definition of World Health Organization (WHO) waste is something that is not used, not used, not liked or something that is discarded that comes from human activities and does not happen by itself.

The Waste Management Act No. 18 of 2008 states that waste is the remnant of human daily activities and / or from solid natural processes.

And also American public health experts make boundaries, waste is something that is not used, not used, not liked, or something that is thrown away, which comes from human activities, and does not happen by itself. From this limitation it is clear that waste is the result of human activities being thrown out because it is no longer useful. Thus according to Notoatmodjo, 2003 waste contains the following principles:

1. The existence of something solid objects or materials

2. There is a direct / indirect relationship with human activities

3. The object or material is no longer used 


\section{Relationship of Waste to Society and the Environment}

Relationship of Waste to Society and the Environment According to Chandra, Budiman (2006) waste management in an area will have an impact on the community and the environment itself. The effect is of course there are positive and also negative ones. The positive effects of this waste management on the community and the environment include:

a) Waste can be used to hoard land such as swamps and lowlands.

b) Waste can be used for fertilizer

c) Waste can be given for animal feed after undergoing a predetermined management process to prevent the adverse effects of waste on livestock

d) Waste management causes less space to breed insects or rodents

e) Reducing the incidence of infectious disease cases that are closely related to waste

f) Clean environmental aesthetic conditions lead to the excitement of people's lives

g) Good environmental conditions reflect the cultural progress of the community

h) Good environmental conditions will save the health expenditure of a country so that the funds can be used for other purposes.

While the negative effects of waste on health, the environment as well as the socio-economic and cultural community, include:

1) Effects on health

a) Poor waste management will make waste a breeding ground for diseases such as flies or mice

b) Incidence of dengue hemorrhagic fever will increase due to vector of living and multiplying diseases in garbage cans or used tires containing rain water

c) Occurrence of accidents due to littering such as injuries due to sharp objects such as iron, glass and so on.

d) Psychosomatic disorders, such as shortness of breath, insomnia, stress and others.

2) Effect on the environment

a) Environmental aesthetics are less pleasing to the eye

b) The process of spoilage of garbage by microorganisms will produce certain gases that cause a foul odor

c) Combustion of rubbish can lead to air pollution and wider fire hazards

d) Disposing of garbage into the drainage will cause water flow to be disrupted and the drainage will become shallow

e) When the rainy season comes, accumulated garbage can cause flooding and cause pollution in surface water sources or shallow wells

f) Flood water can cause damage to community facilities such as roads, bridges and waterways.

3) Influence on the socioeconomic and cultural community

a) Poor waste management reflects the social and cultural conditions of the local community

b) The condition of the environment that is not good and dirty, will reduce the interest and desire of others (tourists) to come visit the area

c) Can cause disputes between local residents and the management (for example the Bantar Gebang landfill case, Bekasi)

d) The number of cases of illness increases and decreases working days and decreases community productivity

e) Damaged environmental repair activities require large funds so that funds for other sectors are reduced

f) Declining regional income (foreign exchange) due to a decrease in the number of tourists followed by a decrease in local community income

g) The accumulation of rubbish on the roadside causes traffic jams that can hamper the transportation of goods and services.

\section{Implementation Method}

How to overcome the problems that occur in the partner communities as described, the Community Partnership Program offers several methods of approach that can help in solving existing problems, namely by conducting training and counseling methods and guidance, and and environmental health.

The Community Partnership Program Implementation Activities will be given training and assistance: 


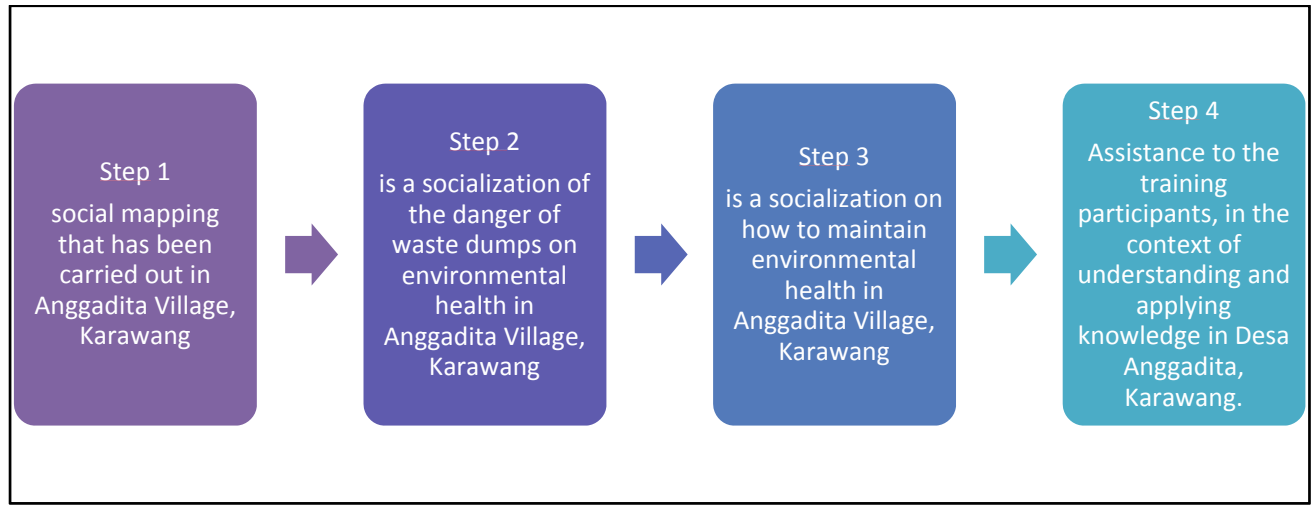

Figure 1: Stages of Training Activities.

\section{Dissemination of the danger of waste dumps on environmental health}

This socialization is directed to provide knowledge to the public related to the dangers of landfill waste for the health around the neighborhood.

\section{Dissemination of ways to protect environmental health}

This socialization is directed to provide knowledge to the public regarding how to maintain health around the neighborhood.

\section{Assistance to the trainees}

Assistance to the training participants, in the context of understanding and applying knowledge in Desa Anggadita, Karawang.
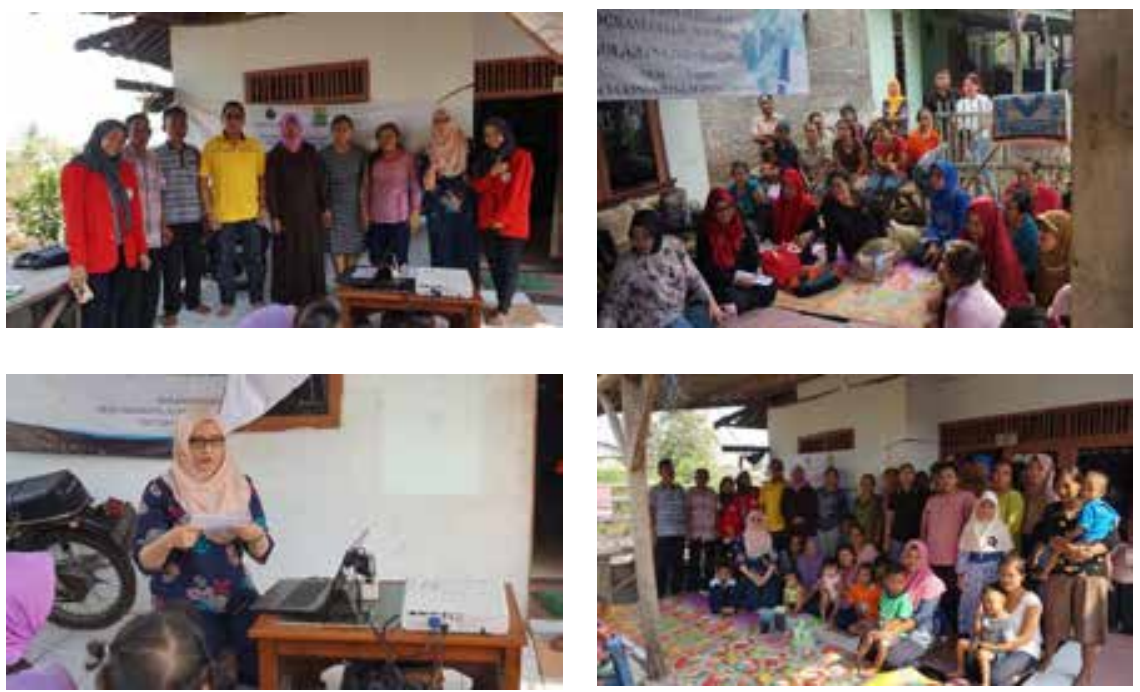

Figure 2: Dissemination Activities

\section{Results and Discussion}

Anggadita Village utilizes the potential of 5,500 $\mathrm{m} 2$ land for fish enlargement and fishing activities. there is an untapped land of $5050 \mathrm{~m} 2$. This untapped land will later be utilized to build facilities for sorting, processing and recycling waste to make the Citarum river basin fragrant, clean and maintained. The area of Anggadita Village is $2.94 \mathrm{Km}$.

The problem of waste dumps in Anggadita Village must be resolved from many aspects. Starting from the addition of the fleet of garbage transporters, routine garbage transportation, and the role of the community to participate in managing waste. The waste problem is not only burdened by the local Sanitation Department. However, from the many available methods, it seems that it will not be able to overcome the waste problem. because it needs the active role of the community in managing and processing waste. For this reason, the community can continue to develop a culture of reduce, reuse, recycle (3R), composting and others in their respective regions. 


\section{Conclusion and recommendation Conclusion}

Overall, participants of the socialization were dominated by housewives in the village of Anggadita, Karawang. The atmosphere of the socialization was quite lively, because of the curiosity of the participants to be able to protect the environment from the danger of landfills. Overall, the participants stated that social activities are interesting, knowing a lot about new things in this socialization activity. Information related to how to protect the environment from the impacts of hazardous landfill.

Initial questionnaire participants from 35 people, as many as 20 people still do not understand the dangers of landfill for health in the surrounding environment and how to maintain health. Participants of the final questionnaire of 35 people, as many as 29 people have understood the dangers of landfill for health in the surrounding environment and how to maintain health. In addition, this activity can be used as a means of communication and socialization of Mercu Buana University to the community, as well as a form of social responsibility of the Tri Dharma College Higher Education Institution..

\section{Recommendation} activity.

It is recommended to make routine scheduling and mentoring activities in running the program or

\section{Acknowledgment}

Gratitude and honor to the editors who have reviewed the ICCD 2019 paper

Universitas Mercu Buana Jakarta

Dr. Inge Hutagalung, M.Si., Head of Community Service at Mercu Buana University

Dudi Permana Ph.D., Head of Management Undergraduate Program

Tine Yuliantini, MM, Secretary of Management Undergraduate Program

Ryani Dhyan Parashakt, SE, MM. Secretary of Management Undergraduate Program

Mochamad Soelton, S.Psi.,MM.,CHRMP., Psikolog

\section{References}

Antara Jabar 2018. Volume Sampah Di Sungai Citarum. (https://jabar.antaranews.com/berita/70132/volume-sampah-di-sungai-citarum,diakses tanggal 01 September 2018).

BBC,2018.Sungai Citarum Yang Tertutup Lautan Sampah. (https://www.bbc.com/indonesia/media-43959742, diakses tanggal 01 September 2018)

Chandra, Budiman. 2006. Pengantar Kesehatan Lingkungan. EGC. Jakarta

Dinas Lingkungan hidup,2018. Data Sampah Masuk TPST Bantargebang 2015. (http://data.jakarta.go.id/dataset/jumlah-sampah-masuk-tpst-bantargebang-tahun-2011, diakses tanggal 29 Juli 2018).

Kompas,2017. Setiap Hari, Ada 1.500 Ton Sampah Dibuang di Sungai Citarum.

(https://regional.kompas.com/read/2017/06/06/10000031/setiap.hari.ada.1.500.ton.sampah.dibuang.di.s ungai.citarum, diakses tanggal 01 September 2018)

Limbong Jendrianto, 2015,"Efektivitas Pengelolaan sampah, melalui bank sampah (Studi kasus Bank Sampah Pelita Harapan, Makassar).

Malayu Hasibuan,SP.2002. Manajemen Sumber Daya Manusia, Edisi Revisi, Jakarta: PT.Bumi Aksara.

Notoatmodjo, Soekidjo. 2007. Kesehatan Masyarakat Ilmu \& Seni. Rineka Cipta. Jakarta

Notoatmodjo, Soekidjo. 2005. Metodologi Penelitian Kesehatan. Rineka Cipta. Jakarta

Poskota News,2018. Jakarta Barat Kebut Bank Sampah di Kecamatan. (http://poskotanews.com/2018/02/01/jakarta-barat-kebut-bank-sampah-di-kecamatan/ ， diakses tanggal 29 Juli 2018).

Profil Bank Sampah Indonesia, 2013, Kementrian Lingkungan Hidup.

Siagian,Sondang P,2001."Manajemen Sumber Daya Manusia", Cetakan ke Tujuh, Jakarta:Radar Jaya Offset.

Suradinata,Ermaya, 1996. "Manajemen Sumber Daya Manusia-Suatu Tinjauan Wawasan Masa Depan", Bandung:Ramadan.

Suryani, Elvira, 2016. Manajemen Pengelolaan Bank Sampah di Kota Bekasi ,Jurnal AKP, 6, 68-71.

\section{Documents}

SK SNI S-04-1993-03 tentang Spesifikasi Timbulan Sampah untuk Kota Besar dan Kota Sedang 